\title{
Rectification of legal sex: social expertise
}

\begin{abstract}
The aim of this article is to provoke reflection and share the experience of the actions of the judicial social worker in the process of correcting the legal name and sex of transvestites and transgender people. To do this: (a) We analyze the demand for rectification of name and legal sex in the light of social work, based on ethical and political assumptions; (b) We share the experience of acting in the process of correcting the legal sex of a transsexual woman and analyzing the projecting of sexism in transvestism and transgender experiences; and (c) We point out some propositions that allow the social workers to reflect and discuss their professional training and work in the process of legal sex an name correction, as well as to apprehend the dimensions of capitalism and to obtain subsidies to substantiate interventions in the social demands that are present in the professional routine.
\end{abstract}

Volume 3 Issue $3-2019$

\section{Thais Felipe Silva dos Santos, Maria Lúcia Martinelli}

Department of Social Work, Pontifical Catholic University of São Paulo, Brazil

Correspondence: Thais Felipe Silva dos Santos, Postgraduate Program in Social Work, Pontifical Catholic University of São Paulo, Brazil,Tel 55I 1963954226, Email thaislipe@gmail.com

Received: April 30, 2019 | Published: June 07, 2019

Keywords: social skills, transvestility, transsexuality, ethics, social worker

\section{Introduction}

This report originates from the reflections and acting as a social and legal assistant at the family and succession courts of the Court of Justice of São Paulo, Brazil. The goal is to share the experience of social expertise in the process of legal sex correction of transvestites and transgender people. We present a brief analysis of the professional performance in such a demand, based on the intransigent defense of human rights, one of the principles of the Code of Ethics of the social worker of 1993, to argue and affirm rights of a particular group, which need to have the birth registration modified so that the identification document expresses the person that she/he is, in their daily life-since, in Brazil, there is no law regulating such rectification. This is not a usual assignment to the social worker of the family courts; it reports the reaction of some social workers at the judiciary when faced with the request for social expertise in a process for rectification of legal sex in the birth certificate of a transsexual woman.

In the past, in the family and succession courts, the judicial social worker was called to examine the demands of guard, change of custody, regulation of visits, guardianship, parental alienation, among other measures to children, teenagers, the elderly and people with disabilities. It is worth noting that, according to Baptista, ${ }^{1}$ the way professionals deal and act reflects their world views, their theoretical framework and their basic conjecture, aspects that guide the ruler with which they measure the demands posed. In 2015, the court where the author works was faced with its first case of request for correction of legal sex (the person had a female name, but the birth certificate read 'sex: male', as will be seen ahead). The family court then assigned the socio-legal social worker of the family courts to start the demand for legal sex correction. Until then, this rectification was not a demand for the technical sector of social workers. The reality required qualifying professional practice in a specific dialectical movement, "[...] A movement of action in which the professional elaborates and builds new knowledge". ${ }^{1}$ According to the same author, it is a spiral movement, which involves action, knowledge and action, in which we depart from the particular issue presented, and after analyzing it in the light of the universal, we return to the particular, with new knowledge, in a "threefold dialectical movement".

The new fact called on the professionals to reflect: Is this demand pertinent to the performance of social-legal services? If so, what are the elements necessary for the analysis of the social aspect of the situation presented? In our view, it was about making a critical reading of the situation presented, through the lenses of the theory of historical-dialectical materialism, a current that underpins the professional thought, to assess whether what was being proposed was pertinent to the scope of knowledge of the social worker. We consider that this article is part of the pressing themes that arise for the social-juridical service, but not only for this area of professional practice, because transvestistes and transgender people are inserted in society and resort to the whole range of services and policies in which the social worker is inserted. We seek; therefore, to incorporate new questions and challenges that arise for the professional practice, contemplating the process of materialization of the ethical-political project with answers to the social needs of a historical time. According to Simionatto, ${ }^{2}$ the demands for the social worker arise from the need for survival of different segments in everyday life and indicate "a set of needs that must to be situated in the complexity of capitalist transformations." ${ }^{2}$ The idea is to contribute to the comprehension and expansion of the debates about sex, besides understanding how the intervention in this reality can add knowledge to the profession and cultivate a new social order. We understand that, when talking about a society's project, we approach the class dimension and the politicalprofessional dimension in the tension of power relations, such as mediation between professional projects and social projects: on the one hand, the social workera with their values and ethics and, on the other, the judiciary, which makes up the ideological apparatus of the dominant class.

It should be clarified that legal sex is the one informed on the birth certificate; it is the civil sex indicated at the time of the registration of the new born, according to the biological characters of the apparent sex, according to Ventura. ${ }^{3}$ With the current medical techniques, this sex is known even before the child's birth, and predicts names, behaviors and expressions. In Brazil, the civil certificate gives the juridical objectification of the social being, supported by the legalnormative superstructure of capitalist society. The social workers' ethical-professional principles are incisive in asserting freedom as a central ethical value, social justice, equity, professional practice, non-discrimination on gender identity issues, the commitment to eliminating all forms of prejudice, and encouraging diversity and discussion of differences, among others. The diversity, whether of "culture, race, ethnicity, generations, life forms, choices, values, conceptions of the world, beliefs, symbolic representations", ${ }^{4}$ among other differences, is an element that constitutes the whole of humanity and makes part of the richness produced by the human race. "The 
identities that unite certain social groups, differentiating them from others, should not result in relations of exclusion, inequality, discrimination or prejudice" ${ }^{4}$ The limits of the society of the capital must not lead to conformism or paralysis of the social worker, because in everyday life, social beings produce and reproduce the conditions necessary for their survival and, in this movement, they use their creative capacity, which generates new needs, and modifies the course of history, so we say that history is humanized, in the sense that it is made by the social beings. To act ethically implies denaturalizing social relations in capitalism and being a social worker committed to the professional ethical-political project, with its democratic values.

The transidentities question the institutions, because their histories were made invisible; they illustrated pathological narratives; or else are linked to the sex market. The proposal we advocate is a social look at these individuals, because we understand that sex is socially constructed. It is through this focus that we consider social expertise pertinent. In this sense, the reflections on and about the transvestites and transgender people are a tool for collective subjects, who lend their voices to talk about groups that have been historically silenced. As Mombaça ${ }^{5}$ points out, such reflections are, at the same time, a political and ethical instrument for incorporating the differences of the collective subjects to the class struggle, from the perspective of marxist social theory.

Analyzing the working class from its particularities, and, in the specific case, transidentity, is a skill under construction among Brazilian social workers. In recent times, they have focused on the particularities of class, notably the dimensions of race, ethnicity and gender, as elements that also contribute to structure the capitalist mode of production. Finally, we agree with Ribeiro, ${ }^{6}$ when she teaches that reflecting on the "place of speech" is to provoke contradictions, but mainly it is an ethical posture, while destabilizing and provoking tensions in order to make room for potentialities and the construction of other referentials.

\section{Description}

\section{The experience of the socio-legal social worker}

If it is true that transvestite and transgender people existe in society, the movement of history caused them to access the judiciary with their pleas of rectification, that is, emerged from social life as a reality, which provoked the analysis and positioning of sociojuridical social workers on the diversity of sex and its implications for the individual, in our historical time. Expanding the knowledge about the transidentities ${ }^{2}$ was only possible, for us, from the tension

'According to Djamila Ribeiro, "the notion of 'place of speech', and the activism that derives from it", may be considered one of the most debated subjects in the discussions about worldviews, experiences and localized knowledge, and derives mainly from black feminisms, which soon identified the impossibility of feminism that emerged in the 1960s to account for the various issues that pervaded racialized women. Djamila Ribeiro shows how the concept articulates with the right to a voice and to listening to marginalized voices, in which it is important that each individual be able to identify their place of speech in a social structure with hegemonic markers in relation to gender, race, and social class. For the author, the term may have arisen from the tradition of discussion about feminist standpoint, diversity, critical racial theory, and "decolonial" (not colonial) thinking.

${ }^{2}$ In this article, we also use the transidentity vocabulary to refer to people who transcend the normative, that is, the norms of sex in capitalist society. Cis, cisgender, cisnormative, or cisgenerity, refers to "the condition of the person whose gender identity is in accord with what has been socially attributed to him, based on gender markers" (Jesus, 2012: 347). provoked by the transvestites and the transsexuals, who transcended the hegemonic norms of gender and entered the judiciary to request the rectification of name and sex in the birth certificate. We understand social expertise as a process through which the social worker conducts "examination, survey or evaluation" of social situations with the purpose of issuing a social report to subsidize the judicial decision. The proximity to transitivity brings us to the field of ethics and human emancipation, so it is not a debate of a collective, but rather a social place that has as its horizon a fairer society. The diversity is an object of ethical reflection and Ferreira ${ }^{7}$ adds that it is an option, also political, to occupy the diversity of sex. The Transgender Europe non-governmental organization (TGEU), which monitors murders of transgender individuals in the world, revealed that Brazil, in absolute numbers, is the 'champion' of violent deaths of transvestites and transsexuals in the period from 2008 to 2016.

In 2015, the process submitted to the analysis involved a transsexual woman, who had succeeded in rectifying the registry legal name on the public records court, and carried on her civil record a feminine name, but, in the sex field, the word "male". At that moment, the Court of Public Records understood that it could not alter the legal sex in consonance with the name, because it understood that this alteration was "change of person", subject to the competence of the Family Court and it is due; that is how, after legal rites, the process entered the technical sector of social service. We did the critical reading of the records, in order to investigate the concerns that would emerge from the beginning, and to establish a theoretical-practical approach to the social context presented. For this, we focused on the curricular guidelines, the code of ethics, and the legislation that regulates the profession. By outlining the theme, at first, through bibliographic research on transsexuality, with the expansion of readings, we were focused on the issues of ethics, sex and identity. We take these contents mediated by the reflection on the identification of the social question, ${ }^{4}$ the object of work of the social worker, in order to legitimize (or to remove), the intervention of the social-juridical service. The objective of social expertise was to understand the identity of the woman (hereby called Daniela) in society and, for this, we needed to know her insertion in the private world (friends, family, social conviviality) and in the world of work, indispensable contacts for the construction of the social report. We initiated social expertise ${ }^{5}$ with Daniela $^{6}$ through an interview at her home, since we believed that the domestic environment could facilitate the rescue of her socio-historical journey,

${ }^{3}$ According to Article 464 et seq. of the New Code of Civil Procedure ${ }^{4}$ According to Iamamoto (2012:47-48), "The social question is inseparable from the form of organization of capitalist society, which promotes the development of the productive forces of social work and, on the other hand, expands and deepens the relations of inequality, and poverty. This is a structural law of the process of capitalist accumulation. The social question concerns all the expressions of social inequalities engendered in mature capitalist societies, unthinkable without the intermediation of the state. It has its genesis in the collective character of production, as opposed to the private appropriation of human activity itself-labor-of the conditions necessary for its realization, as well as its fruit. It is inseparable from the emergence of 'free labor' which depends on the sale of its labor force with the means of satisfying its vital needs. The social question, therefore, expresses the economic, political and cultural inequalities of social classes, mediated by disparities in gender relations, ethnic-racial characteristics and regional formations, calling into question large segments of civil society in access to the goods of civilization). ${ }^{5}$ Social expertise" consists of an articulated use of several other instruments that allow us to approach the subjects involved in the situation in analysis" (Mioto, 2001:153).

${ }^{6}$ The name was changed and some data modified to preserve the identity of the applicant. 
as we consider it a place of safety and comfort for the author of the judicial process. Her life story included broken bonds with family and friends, pseudo-acceptions, detailed accounts of her vision of being a woman; moments of exclusion from the labour market; repression of her experience of sex; stories of prejudice and discrimination; and in the midst of difficulties, her then recent success in obtaining the civil record with her name, reflecting her feminine experience. According to Diniz, " "The identity of a person only makes sense if it corresponds to his/her social reality."

In our understanding, which is consistent with Cisne and Santos, ${ }^{9}$ this dimension of the sex experience is not detached from the broader class relationships structuring the capitalist society. The groups discriminated for their experience of sex is subjected to sophisticated forms of domination, exploitation and oppression, alike the whole of working class. What intensifies the disfavor of these groups is that the experience of sex, in dissonance to the normalized, further heightens the violence suffered, transforming the differences into disadvantages, "because their differences are not socially accepted and in this case we are entering the field of ethical and political issues, a space of struggle for the recognition of the right to the difference, one of the dimensions of human rights". ${ }^{4}$ The media present the murder of transvestites and transgender people, in crimes that, most of the time, occur in a brutal way, linked to the fact that they have a sex experience that transcends the expectations attributed to their biological sex. The social being, as a public being, in practical life individualizes him or herself, becomes singular, and acts to preserve its life, being concerned with the material survival. The reproduction of social life in capitalism synthesizes a set of economic, social and political inequalities of the class society, but, on the other hand, forges ruptures that enable mankind to overcome the current conditions, as Semeghini ${ }^{10}$ recalls. Martinelli ${ }^{11}$ teaches that identity requires a dynamic and constant social movement, because the construction of social identity is a double-handed way, since "it encompasses what the individual aims to demonstrate and also the way society seizes the information transmitted by him/her, hence it is said that the identity is not a solitary process“". ${ }^{12}$

We interviewed a friend of Daniela's, a person who accompanied her exteriorization and with whom she maintained a relationship of friendship. This friend brought elements about Daniela's social and leisure life, corroborating her experience of the female sex. Daniela had a professional insertion in the area of international relations; her resume was qualified; the company had a diversified profile for its employees and her technical capacity overcame the condition of transsexual woman, so it was possible to verify. She was the first transwoman hired. By inquiring on Daniela's social recognition, we interviewed her employer. In his speech, references to Daniela were made with the use of feminine vocabulary, denoting her appearance and her behavior with characteristics usually attributed to women. We must clarify that, since the beginning of the technical procedures, she had been aware of the objectives and scope of the social expertise and had knowledge of the procedures that would be performed, without this putting her on display before colleagues at work, since the interview took place with her boss, who recognized her condition as a trans woman, and, at that location, the objective was not to interact with the applicant, but to obtain information that corroborated her social recognition of sex. Daniela is an exception, because, as the Federal Council of Social Workers warns, ${ }^{13}$ transvestites and transgender people are usually pushed into the sex market, "without the majority of them having the possibility of choosing other forms of work, when desired" ${ }^{13}$ Moreover, it cannot be lost in view that workspaces are sexualized, that is, "divided into rigid positions of female or male".

We are sure that the relationship between capital and work is irreconcilable, because this dynamic divides society between owners of the means of production and salespeople of the workforce; and it is imperative that we understand "that she has a body that is situated in a society in which signs also act to stigmatize and exclude". ${ }^{14}$ In the society of the capital, the bourgeois freedom is that of the isolated individual, as Barroco ${ }^{15}$ points out, referring to Marx's reflection on freedom, for he "describes exactly the liberal maxim still reproduced in everyday life, two centuries later: The idea that "my freedom ends when the other' begins." According to the author, this liberal maxim suggests the idea that the social being enjoys absolute freedom, as if men did not live in society and enjoys freedom in a simultaneous manner. Therefore, it is impossible to think of an isolated subject of social relations; in contact with other beings, there will be processes of interaction, ruptures, reproduction of social life, and resistance. Thus we understand that the experience of sex goes beyond self-declared and "gender expression", but is also immersed in the general conditions of capitalist society, so the isolation, often declared in social expertise, does not, in fact, be configured in everyday life of the transvestite and transsexual person considering the ontological conditions of the social being. Lessa ${ }^{16}$ states that "there is no singular human act but within a social totality, there is no individuality outside the social totality. It is the evolutionary movement of the human genre, as totality, which constitutes the founding impulse and the predominant moment of the individuation process." Sex diversity is not separated from the macro structural determinations of capitalist society; however, it must be considered that the expressions of social issues will be different, depending on the subject's class in the capitalist mode of production. Veloso ${ }^{17}$ recalls that it is important to note the causes at the roots of the inequity of the social relations of sex, because in this unveiling will be found the social means for its overcoming. According to Cisne and Santos, ${ }^{9}$ cisnormative class relationships are structurating and coextensive systems in capitalism. As we mention the coextension of the social relations of sex, we are saying that the dimensions of class, race and gender pervade social practices, and their separation is only possible for didactic purposes, because in practice they are connected. The authors point out, based on Kergoat,, ${ }^{9,18}$ that the social relations of sex are, at the same time, relations of "symbolic domination, of physical oppression and of material exploitation". Kergoat, ${ }^{18,19}$ points out that social relations of sex and social division -and, we add, sexual work-are imbricated and inseparable spheres. Thus, we analyze that the social relations of sex are projected on the world of work, since both are associated in and for the accumulation of capitalist riches. Therefore, even if it is an individual aspect of the subject, the experience of transidentity is based on the sociability of the being. According to Bento, ${ }^{20}$ "The transsexuality [and we add the transvestism] is one of the multiple expressions [...] that emerged as an inevitable response to a system that organizes social life grounded in the [sexual] production of subjects." Cisne ${ }^{21}$ recalls that "economics and politics are [...] Dialectically articulated in the dynamics of the determination and reproduction of social classes". Ribeiro ${ }^{6}$ warns that "the norm is not merely to speak of identities, but to unveil the use that institutions make of identities to oppress or privilege". As the informations about the social recognition of the transwoman Daniela were collected, we ended the social expertise and set out for the elaboration of the report. 


\section{Lessons learned}

Along the data collection, we understood that this was a legitimate demand from the social service, as the expressions of social issues that emerge in the singular experience of transgender and transvestiste people are discussed in the report: prejudices; discrimination; bathroom use; the embarrassment of presenting an identification document or credit/debit card use; exclusion or precarious insertion in the labor market; disruption of family bonds; scarce social circle of friendship; fatal violence; finally, conditions that evidence the high vulnerability, the personal and social risks to which transidentity subjects are subjected due to compulsory cisgenerity. The capitalism, when engendering social relations of sex, attributed conventions that are assumed as feminine and masculine, and thus established the control of the body and imposed contours for the domination/ patriarchal exploration, according to Cisne. ${ }^{22}$ Bento $^{20}$ adds that capitalism has created "the bodies of women as the only habitable place for the feminine, and those of men, for the masculine. It is as if there is an essence of its own, singular to each body, unreachable by the other", as if they were innate conducts arising from nature itself. By this perspective, dimorphism ${ }^{7}$ and social organization should be dictated and guided by nature. As if the mannerisms attributed to the masculine and the feminine were not learned in the different cycles of life of the social being and according to the local culture of where he/she lives. In this scenario of expressions of the social issue, the intransient defense of the rights of trans and transvestite people is urgently required, and it is up to the social worker to radically conjugate the theoretical, ethical and political principles that guide the profession. We verified that the elements that enable such defense are in the individual's social environment, for they can contribute to confirm, or not, their social recognition. According to Rocha and Santos, ${ }^{12}$ when we gather elements "from the public world of the subject, we look back to the existence of professional, institutional, religious bonds", to their identification in social circles of coexistence; notes that demonstrate the experience of sex of the individual for which he is socially recognized. We observed that the challenge posed to the social expert is to apprehend the network of social relations of the transidentities. It seems to us that, by legal strategy, or by a precarious social circle, the references on social life and activities are scarce. Given the non-scope of this information, in the course of the social expertise, we consider that the social report remained impaired.

Based on the analyses of Almeida ${ }^{23}$ on racism, we can reflect about the transidentities. The author warns that workplaces are marked by a form of sex discrimination that stratifies and affects the social ascension, the recognition and the material sustenance of the members of the social group not cisgender. We apply the author's warning ${ }^{23}$ also to the transidentities, by that the absence of transvestite and transgender people in spaces of power and prestige, brings to light the sexualized social inequality. The wage differences, the high risk to vulnerabilities and imminent violence are expressions of the social issue pointed out by Kergoat ${ }^{18}$ originating from the syntagma domination-exploitation-oppression, generated by the social relations of sex, which are projected particularly to discriminated groups, such as transvestites and transgender people. To recognize human diversity, based on the social relations of sex in the classist perspective, means

${ }^{7}$ Sexual dimorphism, or binary, is an ideology constituted by the assertion that women and men are radically different; this distinction is founded on biological bodies; and therefore is unchanging and unquestionable. (Available at: http://www.cfess.org.br/arquivos/CFESS-Caderno04-Transfobia-Site.pdf. Access: 23 Feb. 2019). to encompass the exploitation, domination and oppression to which are subjected the groups who oppose the common experiences, against what is ideologically programmed by the capitalist society. Hierarchical relationships contribute to sustaining the capitalist production and reproduction system, with the sexual division of work, by attributing asymmetric valuation among people. Oliveira ${ }^{24}$ recalls that "society divides jobs between those typically feminine and those typically masculine", and for this reason, unpaid house work is left to women and wage labor, more valued, is destined preferentially to men, "showing, thus, that, by dividing them, they are hierarchized." In view of the hierarchization of social relations of sex and the world of work, it is inferred that the most precarious posts will be filled by transvestites and transgender people, since the institutions attend to their economic and political interests, so that the prejudice that structures society also makes up the occupational spaces. The definition of heteronormative bases, of previously defined identities, contributes to the production of capitalist society, grounded in the sexual division of labor.

According to Nogueira, ${ }^{25}$ "it is necessary to analyze the sexual division of labor as a political relationship between the sexes". In addition, Nogueira ${ }^{25}$ warns that the sexual division of labor "conforms roles and naturalizes stereotypes". The capitalist mode of production generates a non-place, in the social imaginary, for some subjects, who become susceptible to all kinds of violence. We understand that the work of the social worker in the process of rectification of name and legal sex allows for thinking of possibilities of rupture with the status quo, aiming at transforming society to have diversity as one of the human dimensions with multiple variables. Yazbek ${ }^{26}$ suggests that changes in the society of the capital urge the social worker to deploy the construction of mediations and strategies of resistance within the socio-occupational spaces, in alliance with the demanding subjects, and, in the particular case of the correction of name and legal sex, to allow to bring to the legal-normative environment the discussion of sex as a social construction and identity as attribution, recognition and construction. ${ }^{27}$

\section{Final propositions}

The prospect here is not evidently to assess a professional performance, nor is it the case to build scripts for intervention in such processes. Instead, the idea is to provoke reflection on the demand that was made to social service and inquire about the intervention of the social worker. ${ }^{28}$ We sought to apprehend the structural dimensions of capitalism and obtain subsidies to substantiate interventions for the rectification of name and legal sex of transvestiste and transgender people. From a political standpoint, we understand that transvestite and transsexual movements can provoke the discussion about diversity of sex and open ways to think about the experiences of the subjects. When preparing our social report, we analyzed the social situations presented, we added elements in the perspective of overcoming tolerance, in search of an egalitarian society, which is based on respect and valuating human diversity as a cultural heritage Jesus. ${ }^{29}$ We assess that the work developed in the process of rectification of legal sex in the birth certificate can contribute to improve the lives of transvestites and transsexual people, as in the production the individual's other documents, the civil record becomes paramount to the juridical-normative identity. In the contemporary world, sociohistorically discriminated groups begin to demand their place in the law; their race, ethnicity and sex practices become elements of social identification and objects of reflection, as they come out of 
invisibility. In this context, the rainbow of human diversity emerges in its multiple dimensions. In this sense, we call upon the fundamental role of the state as a guardian of human rights. In the case of Daniela, we have issued a favorable opinion, from the social point of view, for the rectification of legal sex in the civil registry, since the conviviality of the applicant demonstrated that she was a socially recognized person as belonging to the female gender. Although the reflection on transidentity came from a need to respond to a professional demand, the approach led us to questioning the norms of sex identification, the subjects' places in the class structure and to approaching the transvestite and transsexual subjects, who make up workers. We argue that it is our ethical and political role to act in favor of diversity, as we broaden our gaze on the possibilities of social beings' experiences, including by expanding our questioning to other areas of knowledge with which we share workspaces. We know, through going to events on transsexuality/transvestility, that people have reservations to participate in an expertise, but the judicial processes are private and have proper rites. We understand that, for the rectification of name and legal sex, the legislative scope is the way. ${ }^{30,31}$

In June 2018, the National Council of Justice (CNJ) ${ }^{32}$ edited the Provimento 73, which regulates that transvestite and transgender people can make the rectification of the civil and marriage registry directly at the notary, by self-declaration. However, even in the face of this determination, there are news and denunciations by the National Association of Transvestites and Transsexuals (Antra in Portuguese) ${ }^{8}$ that many notary offices do not follow this determination, depending on the prejudice and conservatism of the person responsible for the said organ, thus confirming that prejudice and conservatism provoke exclusion for the people who dared to break with the capitalist norms of sex. We have in mind that the notes made in the article may contribute to the reflection of the social and legal assistant and legitimize the realization of social expertise from the professionals themselves, in view of the expressions of the social issue that arise in singular experiences of transidentities. Finally, we pledge to respond to the demands that emerge from the daily life of the family courts, notably with regard to the rectification of name and legal sex of transvestite and transgender people, with theoretical, ethical, political and technical competence, based on the theoretical-methodological frameworks that ground the professional knowledge, in order to avoid conservative and pathological practices toward the subject under analysis and, instead, assess it in the social totality.

\section{Acknowledgments}

None.

\section{Conflicts of interest}

The author declares that there are no conflicts of interest.

\section{References}

1. Baptista MV. Research in professional practice. Research in social work. Sao Paulo, Portugal: You see, CPIHTS; 2006. 285 p.

2. Simionatto I. The ideocultural expressions of the current capitalist crisis and its theoretical-political influence. In: CFESS, ABEPSS, editors. Social rights and professional skills. Brasília, São Paulo: Cortez; 2009. $873 \mathrm{p}$.

3. Ventura M. Transsexuality in court: health and citizenship. Rio de Janeiro: EdUERJ; 2010. 164 p.

${ }^{8}$ Antra, 2019 Available at: https://antrabrasil.org/denunciacartorios/. Access: 20 Apr. 2019.
4. Barroco MLS. Ethics, human rights and diversity. Russia: Special Notebooks; 2006. 37 p.

5. Mombaça J. Strategic notes on the political uses of the concept of place of speech. 2017.

6. Ribeiro, Djamila. What is a place of speech? Belo Horizonte: Letramento; 2017. $6 \mathrm{p}$.

7. Ferreira GG. Sexual and gender diversity and social service in sociojuridic. São Paulo: Cortez; 2018. 160 p.

8. Diniz, M. C. Right to non-discrimination: transvestite and transsexuality. São Paulo: Studio; 2014. 468 p.

9. Cisne M, Santos SMM. Feminism, sexual diversity and social service. São Paulo: Cortez; 2018. 208 p.

10. Semeghini MIC. Work and social being: a reflection of the ontology of György Lukács. Revista Contradictio. 2009;2(1):1-26.

11. Martinelli ML. Reflections on social service and professional ethicalpolitical project. Emancipation Magazine. 2006;6(1):9-23.

12. Rocha EF, Santos TFS. Transsexuality and transvestibility: social service contributions in the exercise of citizenship. Public transpolitics. Campinas: Social Role; 2017. 224 p.

13. CFESS-Federal Council of Social Service. Transphobia. Series Social Worker in the Fight against Prejudice. 2016. 18 p.

14. Motta D. From universal to specific: intertwining gender, race and class. Cemarx notebooks; 2018. 18 p.

15. Barroco MLS. Human rights or human emancipation? Revista Inscrita, Brasília: Cfess; 2013. pp. 67-73.

16. Lessa S. To understand Lukacs' ontology. 4th edition. Lukács Institute; 2015. $159 \mathrm{p}$.

17. Veloso R. Introductory notes on the discussion of gender relations. University and Society Magazine. 2003;12(29):53-56.

18. Kergoat D. Dynamics and consubstantiality of social relations. Transl. Antonia Marta Campos. Revista Estudos Estudos: Cebrap; 2010.

19. Freitas TV. The current scenario of the sexual division of labor. Work body and life of women: criticism of the market society. São Paulo: Semperviva Feminist Organization; 2007.

20. Bento, B. What is transsexuality. São Paulo: Brasiliense; 2008.

21. Cisne M. Feminism and class consciousness in Brazil. São Paulo: Cortez; 2014. 85 p.

22. Cisne M. Gender, sexual division of labor and social service. 2nd edition. São Paulo: Cortez; 2015. 14 p.

23. Almeida S. What is structural racism? Belo Horizonte: Letramento; 2018. 35 p.

24. Oliveira M. Sexual diversity and centrality of work: the multiple determinations of the exploitation process. Let's take up the colorful flag. sexual and gender diversity in Brazil. São Paulo: Popular Expression; 2018. 320 p.

25. Nogueira L. The patriarchal-heterosexist determinations of capitalist society. Let's take up the colorful flag: sexual and gender diversity in Brazil. São Paulo: Popular Expression; 2018. 320 p.

26. Yazbek MC. Analysis of the social meaning of the profession in the process of reproduction of social relations. São Palo: EdUERJ; 2017. 16 p.

27. Mioto RCT. Social Expertise: proposal of an operational course. São Paulo: Cortez; 2001. 30 p 
28. Iamamoto MV. Professional design, occupational spaces and social worker's work today. Private assignments of the social worker in question. Brasília: Cfess; 2012. 78 p.

29. Jesus JG. Orientations on gender identity: concept and terms. Brasilia; 2012. $42 \mathrm{p}$

30. CFESS-Federal Council of Social Service. Social worker in the fight against prejudice. Brasília: Cfess; 2016a. 24 p.
31. CFESS-Federal Council of Social Service. Code of ethics of the social worker. Brasília; 2012. 22 p.

32. National Council of Justice. Provides for the registration of the change of the name and gender in the birth and marriage seats of a transgender person in the Registry of Natural Persons (RCPN). 2018. 4 p. 